\title{
The evaluation of immunization coverage under mission Indradhanush: a review
}

\author{
Ruchi Thakur ${ }^{1}$, Aanchal Anant Awasthi ${ }^{2 *}$, Neha Taneja ${ }^{1}$, Rajiv Janardhanan ${ }^{1,2}$
}

\author{
${ }^{1}$ Laboratory of Disease and Dynamics and Molecular Epidemiology, Amity Institute of Public Health, Amity \\ University Uttar Pradesh, Noida, India \\ ${ }^{2}$ Health Data Analytics and Visualization Environment Laboratory Amity Institute of Public Health, Amity University \\ Uttar Pradesh, Noida, India
}

Received: 30 August 2020

Accepted: 16 October 2020

\section{*Correspondence:}

Dr. Aanchal Anant Awasthi,

E-mail: aaawasthi@amity.edu

Copyright: (C) the author(s), publisher and licensee Medip Academy. This is an open-access article distributed under the terms of the Creative Commons Attribution Non-Commercial License, which permits unrestricted non-commercial use, distribution, and reproduction in any medium, provided the original work is properly cited.

\begin{abstract}
The government of India introduced mission Indradhanush (MI) to strengthen the routine immunization planning and delivery mechanism. It was launched on $25^{\text {th }}$ December 2014 with an objective to achieve more than $90 \%$ full immunization (FI) coverage in the country. To evaluate universal immunization coverage, barriers encountered for not achieving the target and problem solving in removing the barriers. PubMed and google scholar were used to search the relevant articles. PRISMA tool was used for the review process and for inclusion of potential articles. The studies conducted in Manipur, Madhya Pradesh, Bihar and south Kerala reported successful achievement of MI goal. The minimum FI percentage was $57 \%$ and the maximum was $96.4 \%$. The most common reason for not achievement of the goal was lack of awareness, illiteracy, child illness, fear of adverse effects.
\end{abstract}

Keywords: MI, Evaluation, Awareness

\section{INTRODUCTION}

India's immunization programme, launched in 1985, was one of the largest health programmes in the world. The programme provided vaccination against eight lifethreatening diseases (diphtheria, whooping cough, haemophilus influenzae type B (Hib), tetanus, polio, tuberculosis, measles and hepatitis B) in the entire country. ${ }^{1}$ After the introduction of the UIP there had been steady fall of infant mortality from 80 per 1000 live births in 1991 to 37 per 1000 live births in 2015 (SRS). ${ }^{2}$

As per NFHS-3, the immunization coverage in 12-23 months old children was $43.5 \%$ which has increased to $62 \%$ in NFHS $-4 .^{3}$ On $25^{\text {th }}$ December 2014 union health minister Mr. J. P. Nadda has introduced MI with an objective to achieve more than $90 \%$ FI coverage within the country, which would reduce immunity gaps and strengthen immunization coverage. ${ }^{4}$
According to immunization status estimated from routine immunization monitoring and MI data, it had been estimated that annually more than 70 lakh (7 million) children in the country did not receive all vaccines that were available under the UIP. ${ }^{2}$ The first two phases of MI contributed to a rise of $6.7 \%$ points in FIC according to the integrated child health and immunization survey (INCHIS). Analysing the coverage trend and progress, it had been clearly understood that MI alone is going to be inadequate to reach the target of $90 \%$ FIC by December 2018. An intensified IMI was launched by the honourable prime minister in October 2017 to accelerate vaccination coverage and meet current gaps. ${ }^{4,5}$

The purpose of this review is to examine literature on MI. Specifically, seek to understand evaluation of universal immunization coverage, barriers encountered for not achieving target and problem solving in removing barriers. 


\section{METHODS}

This paper is based on the literature review of assorted articles on MI. PubMed and other database were used to search the relevant articles. Process included assessment of literature using specific keywords such as MI, assessment/evaluation/analysis, awareness/knowledge.

\section{Study selection}

The study selection was done by using the PRISMA (preferred reporting items for the systematic review and meta-analysis) flow diagram to identify data included and excluded, and their rationale for exclusion.

The studies conducted within last five years related to awareness and utilization of MI, assessment of knowledge of care giver regarding immunization schedule in India were included. The studies were screened using their titles and abstracts then, the included studies were further thoroughly reviewed to select the potential articles.

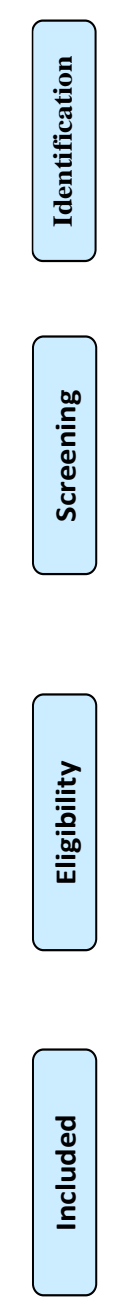

Additional records identified through other sources $(n=18)$

\section{Records identified through database searching $(n=33)$}

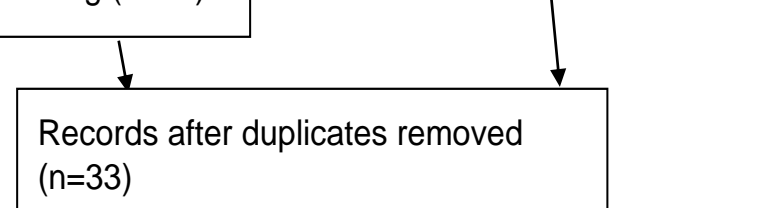

Figure 1: Prisma flow diagram.

\section{RESULTS}

Total 18 studies were reviewed. Most of the study participants belonged to the age group of 12-23 months. Out of 18 studies the minimum sample size was 100, considered in the studies conducted in Bhubaneshwar (urban slum) and Uttarakhand, maximum sample size was 108057 considered in district level analytical based study conducted in 601districts of India. Highest FI status was reported by south Kerala (96.4\%) and lowest reported by study conducted in 601 districts of India (57\%) (Table 1).
Coverage status for individual vaccine for different states

Out of 18 studies reviewed, coverage status for individual vaccination was given in 6 studies. Bihar has the highest BCG coverage (99.21\%) followed by Manipur (98.6\%), Telangana $(96.7 \%)$ and Vellore $(93.5 \%)$. The coverage of Penta (1, 2 and 3) and OPV (1,2 and 3) was found highest in Manipur (98.6\%). Telangana has reported highest measles coverage $(96.7 \%)$ followed by Manipur $(96.2 \%)$ and Bihar $(92.5 \%)$ (Table 2$)$. 
Table 1: Immunization coverage status of various states.

\begin{tabular}{|c|c|c|c|c|c|c|c|c|c|c|}
\hline Name of author & Title & $\begin{array}{l}\text { Year } \\
\text { of pub. }\end{array}$ & Type of study & $\begin{array}{l}\text { Sample } \\
\text { size }\end{array}$ & $\begin{array}{l}\text { Age } \\
\text { (month) }\end{array}$ & State & FI & PI & NI & $\begin{array}{l}\text { Achieved/n } \\
\text { ot achieved }\end{array}$ \\
\hline Prinja et al $^{6}$ & $\begin{array}{l}\text { District level analysis of routine } \\
\text { immunization in Haryana state: } \\
\text { implication of MI in universal } \\
\text { immunization programme }\end{array}$ & 2018 & $\begin{array}{l}\text { Analysis } \\
\text { based study }\end{array}$ & 11594 & $12-23$ & $\begin{array}{l}\text { Haryana (district } \\
\text { level analysis) }\end{array}$ & 74.7 & 21 & 4.3 & $\begin{array}{l}\text { Not } \\
\text { achieved }\end{array}$ \\
\hline Murhekar et $\mathrm{al}^{7}$ & $\begin{array}{l}\text { Coverage of childhood vaccination } \\
\text { among children aged 12-23 months, } \\
\text { Tamil Nadu, } 2015 \text { India }\end{array}$ & 2017 & $\begin{array}{l}\text { Cross } \\
\text { sectional } \\
\text { survey }\end{array}$ & 3150 & $12-23$ & Tamil Nadu & 79.9 & 17.7 & 0.3 & $\begin{array}{l}\text { Not } \\
\text { achieved }\end{array}$ \\
\hline Mohapatra et al $^{8}$ & $\begin{array}{l}\text { A study on awareness and } \\
\text { utilization of MI }\end{array}$ & 2018 & $\begin{array}{l}\text { Cross } \\
\text { sectional }\end{array}$ & 100 & $12-23$ & $\begin{array}{l}\text { Bhubaneshwar } \\
\text { (urban slum) }\end{array}$ & 72 & 28 & $\mathrm{NA}^{*}$ & $\begin{array}{l}\text { Not } \\
\text { achieved }\end{array}$ \\
\hline Singh et al $^{9}$ & $\begin{array}{l}\text { Coverage, quality and correlate of } \\
\text { childhood immunization in slum } \\
\text { under national immunization } \\
\text { program in India }\end{array}$ & 2019 & $\begin{array}{l}\text { Cross } \\
\text { sectional study }\end{array}$ & 550 & $12-23$ & Mumbai & 73.1 & 23.8 & 3.1 & $\begin{array}{l}\text { Not } \\
\text { achieved }\end{array}$ \\
\hline Algotar et al ${ }^{10}$ & $\begin{array}{l}\text { Coverage evaluation of MI } \\
\text { immunization programme in urban } \\
\text { and rural communities of } \\
\text { Ahmedabad district of Gujarat }\end{array}$ & 2019 & $\begin{array}{l}\text { Cross } \\
\text { sectional study }\end{array}$ & 126 & $12-23$ & $\begin{array}{l}\text { Gujarat } \\
\text { (Ahmedabad) }\end{array}$ & 74.5 & 15.18 & 9.52 & $\begin{array}{l}\text { Not } \\
\text { achieved }\end{array}$ \\
\hline $\begin{array}{l}\text { Chavan } \\
\text { et al }^{11}\end{array}$ & $\begin{array}{l}\text { Assessment of immunization } \\
\text { coverage in paediatric population in } \\
\text { Telangana }\end{array}$ & 2019 & $\begin{array}{l}\text { Cross } \\
\text { sectional study }\end{array}$ & 122 & $0-23$ & Telangana & 83.6 & 14.75 & 1.61 & $\begin{array}{l}\text { Not } \\
\text { achieved }\end{array}$ \\
\hline Kameshor et al ${ }^{12}$ & $\begin{array}{l}\text { Coverage evaluation survey of } \\
\text { universal immunization program in } \\
\text { north eastern India }\end{array}$ & 2017 & $\begin{array}{l}\text { Cross } \\
\text { sectional study }\end{array}$ & 210 & $12-23$ & $\begin{array}{l}\text { North eastern } \\
\text { India (Manipur) }\end{array}$ & 91.9 & 6.67 & 1.43 & Achieved \\
\hline Jain et al ${ }^{13}$ & $\begin{array}{l}\text { A study on MI programme under } \\
\text { reproductive and child health } \\
\text { among rural population of } \\
\text { Tikamgarh district of Madhya } \\
\text { Pradesh }\end{array}$ & 2018 & $\begin{array}{l}\text { Descriptive } \\
\text { study }\end{array}$ & 204 & $0-24$ & Madhya Pradesh & 91.2 & 8.8 & $\mathrm{NA}^{*}$ & Achieved \\
\hline Gupta et al ${ }^{14}$ & $\begin{array}{l}\text { Determinants of immunization } \\
\text { coverage in Lucknow district }\end{array}$ & 2015 & $\begin{array}{l}\text { Cross } \\
\text { sectional study }\end{array}$ & 198 & $12-23$ & $\begin{array}{l}\text { Uttar Pradesh } \\
\text { (Lucknow) }\end{array}$ & 74.7 & 11.1 & 14.1 & $\begin{array}{l}\text { Not } \\
\text { achieved }\end{array}$ \\
\hline Francis et al ${ }^{15}$ & $\begin{array}{l}\text { Vaccination coverage and factor } \\
\text { associated with routine childhood } \\
\text { vaccination uptake in rural Vellore, } \\
\text { southern India } 2017\end{array}$ & 2019 & $\begin{array}{l}\text { Cross } \\
\text { sectional study }\end{array}$ & 643 & $12-23$ & $\begin{array}{l}\text { Southern India } \\
\text { (rural Vellore) }\end{array}$ & 84 & NA* & NA* & $\begin{array}{l}\text { Not } \\
\text { achieved }\end{array}$ \\
\hline Mugada et al $^{16}$ & $\begin{array}{l}\text { knowledge towards childhood } \\
\text { immunization among mothers and } \\
\text { reason for incomplete } \\
\text { immunization }\end{array}$ & 2017 & $\begin{array}{l}\text { Descriptive } \\
\text { obs study }\end{array}$ & 377 & $<3$ years & $\begin{array}{l}\text { Andhra Pradesh } \\
\text { (Kakinada) }\end{array}$ & 69 & 31 & $\mathrm{NA}^{*}$ & $\begin{array}{l}\text { Not } \\
\text { achieved }\end{array}$ \\
\hline
\end{tabular}


Thakur R et al. Int J Community Med Public Health. 2020 Dec;7(12):5229-5236

\begin{tabular}{|c|c|c|c|c|c|c|c|c|c|c|}
\hline Name of author & Title & $\begin{array}{l}\text { Year } \\
\text { of pub. }\end{array}$ & Type of study & $\begin{array}{l}\text { Sample } \\
\text { size }\end{array}$ & $\begin{array}{l}\text { Age } \\
\text { (month) }\end{array}$ & State & $\mathbf{F I}$ & PI & NI & $\begin{array}{l}\text { Achieved/n } \\
\text { ot achieved }\end{array}$ \\
\hline Shrivastava et al ${ }^{17}$ & $\begin{array}{l}\text { Predictor of vaccination India for } \\
\text { children aged 12-36 months }\end{array}$ & 2015 & $\begin{array}{l}\text { Analysis } \\
\text { based study }\end{array}$ & 108057 & $12-36$ & $\begin{array}{l}\text { district level } \\
\text { analysis of India } \\
\text { (included } 601 \\
\text { districts of } 34 \\
\text { states) }\end{array}$ & 57 & 31 & 12 & $\begin{array}{l}\text { Not } \\
\text { achieved }\end{array}$ \\
\hline Navaneeth et $a^{18}$ & $\begin{array}{l}\text { Knowledge and perception } \\
\text { regarding immunization among } \\
\text { mothers of under five children: a } \\
\text { community study from south Kerala }\end{array}$ & 2020 & $\begin{array}{l}\text { Cross } \\
\text { sectional study }\end{array}$ & $\begin{array}{l}140 \\
\text { (mother) }\end{array}$ & $<5$ years & South Kerala & 96.4 & 3.6 & $\mathrm{NA}^{*}$ & Achieved \\
\hline Singh et al ${ }^{19}$ & $\begin{array}{l}\text { Awareness attitude and utilization } \\
\text { of universal immunization program } \\
\text { with reference to MI Rudraprayag } \\
\text { town }\end{array}$ & 2020 & $\begin{array}{l}\text { Cross } \\
\text { sectional study }\end{array}$ & 100 & $12-23$ & Uttarakhand & 76 & 22 & 2 & $\begin{array}{l}\text { Not } \\
\text { achieved }\end{array}$ \\
\hline $\begin{array}{l}\text { Trushitkama } \\
\text { et } \mathbf{a l}^{20}\end{array}$ & $\begin{array}{l}\text { Assessment of parent's knowledge, } \\
\text { attitude and practice regarding child } \\
\text { vaccination in rural area }\end{array}$ & 2017 & $\begin{array}{l}\text { Prospective } \\
\text { cross-sectional } \\
\text { study }\end{array}$ & 110 & $<5$ year & $\begin{array}{l}\text { Bangalore (rural } \\
\text { area) }\end{array}$ & 68.1 & 7.2 & $\mathrm{NA}^{*}$ & $\begin{array}{l}\text { Not } \\
\text { achieved }\end{array}$ \\
\hline Singh et $\mathrm{al}^{21}$ & $\begin{array}{l}\text { Immunization coverage among } \\
\text { children aged } 12-23 \text { months: a cross } \\
\text { sectional study on low performing } \\
\text { state of Bihar }\end{array}$ & 2019 & $\begin{array}{l}\text { Cross } \\
\text { sectional study }\end{array}$ & 12331 & $12-23$ & Bihar & 90.85 & 8.8 & 0.35 & Achieved \\
\hline Patidhar et al $^{22}$ & $\begin{array}{l}\text { A cross sectional study to assess the } \\
\text { awareness and satisfaction level } \\
\text { among beneficiaries regarding MI } \\
\text { in selected district of Indore } \\
\text { division }\end{array}$ & 2019 & $\begin{array}{l}\text { Cross } \\
\text { sectional study }\end{array}$ & $\begin{array}{l}207 \\
\text { (care } \\
\text { givers) }\end{array}$ & $\mathrm{NA}^{*}$ & $\begin{array}{l}\text { M.P } \\
\text { (Indore) }\end{array}$ & NA* & $\mathrm{NA}^{*}$ & $\mathrm{NA}^{*}$ & NA* \\
\hline Kaur et $\mathbf{a l}^{23}$ & $\begin{array}{l}\text { Perceived barrier of child } \\
\text { immunization among mothers of } \\
\text { under five children in urban slum of } \\
\text { Ludhiana city }\end{array}$ & 2019 & $\begin{array}{l}\text { Descriptive } \\
\text { study }\end{array}$ & $\begin{array}{l}200 \\
\text { mother }\end{array}$ & NA* & $\begin{array}{l}\text { Ludhiana (urban } \\
\text { slum) }\end{array}$ & $\mathrm{NA}^{*}$ & NA* & $\mathrm{NA}^{*}$ & $\mathrm{NA}^{*}$ \\
\hline
\end{tabular}

*NA indicates not available. 
Table 2: Coverage status for individual vaccine for different states.

\begin{tabular}{|c|c|c|c|c|c|c|}
\hline States & $\begin{array}{l}\text { BCG } \\
(\%)\end{array}$ & $\begin{array}{l}\text { PENTA } \\
(\mathbf{1}, \mathbf{2}, \mathbf{3})(\%)\end{array}$ & $\begin{array}{l}\operatorname{PCV}(1,2,3) \\
(\%)\end{array}$ & $\begin{array}{l}\text { OPV } \\
(1,2,3)(\%)\end{array}$ & $\begin{array}{l}\text { Rota } \\
\text { Virus }(\%)\end{array}$ & $\begin{array}{l}\text { Measles } \\
(1 \text { dose })(\%)\end{array}$ \\
\hline Bihar & 99.21 & 97.37 & $42.8 \%$ & 97.2 & \multirow{6}{*}{$\mathrm{NA}^{*}$} & 92.52 \\
\hline $\begin{array}{l}\text { North eastern India } \\
\text { (Manipur) }\end{array}$ & 98.6 & 98.6 & \multirow{5}{*}{$\mathrm{NA}^{*}$} & 98.6 & & 96.2 \\
\hline Gujarat (Ahmedabad) & 85.71 & 73.96 & & 70 & & 74.65 \\
\hline $\begin{array}{l}\text { District level analysis } \\
\text { (India) }\end{array}$ & 85.94 & $\begin{array}{l}\text { DPT }(1,2,3) \\
=70.78\end{array}$ & & Not given & & 71.22 \\
\hline Telangana & 96.7 & 98.3 & & $\begin{array}{l}\text { OPV and DPT } \\
1^{\text {st }} \text { booster=93.4 }\end{array}$ & & 96.7 \\
\hline $\begin{array}{l}\text { Southern India } \\
\text { (Vellore) }\end{array}$ & 93.5 & 94.05 & & 94.05 & & 85.3 \\
\hline
\end{tabular}

*NA indicates not available

\section{Reason for partial/no immunization}

Most common reason for partial and NI was lack of information/awareness $(69.23 \%)$ followed by illiteracy, childhood illness, fear of adverse effects $(30.76 \%)$ each, mother too busy $(23.07 \%)$, unavailability of vaccination, religion disparity and vaccination site too far away from home (15.38\%) each (Table 3).

Table 3: Reason for partial and no immunization $(n=13)$.

\begin{tabular}{|lll|}
\hline Barriers & Frequency & $\begin{array}{l}\text { Percentage } \\
(\%)\end{array}$ \\
\hline Lack of information & 9 & 69.23 \\
\hline Illiteracy & 4 & 30.76 \\
\hline Child illness & 4 & 30.76 \\
\hline $\begin{array}{l}\text { Fear of adverse } \\
\text { effects }\end{array}$ & 4 & 30.76 \\
\hline Mother was too busy & 3 & 23.07 \\
\hline $\begin{array}{l}\text { Unavailability of } \\
\text { vaccination }\end{array}$ & 2 & 15.38 \\
\hline Religion disparity & 2 & 15.38 \\
\hline $\begin{array}{l}\text { Vaccination site too } \\
\text { far from home }\end{array}$ & 2 & 15.38 \\
\hline
\end{tabular}

\section{Solutions to overcome barriers}

Most of the studies suggested that imparting health education to parents/guardians $(58.33 \%)$ regarding importance of immunization, its benefits, immunization schedule will be helpful in achieving universal immunization coverage and will reduce drop outs rates. $(33.33 \%)$ studies focused on strengthening IEC services. Few studies suggested that measures should be taken to increase institutional deliveries and active involvement of ASHA (accredited social health activist) workers (25\%). $(16.66 \%)$ studies concluded that education to health workers about correct vaccination schedule and need for adherence to the schedule is essential (Table 4).
Table 4: Solution to overcome the barriers $(n=12)$.

\begin{tabular}{|lll|}
\hline Solutions & Frequency & $\begin{array}{l}\text { Percentage } \\
(\%)\end{array}$ \\
\hline Health education & 7 & 58.33 \\
\hline Strengthening IEC & 4 & 33.33 \\
\hline $\begin{array}{l}\text { Promote institutional } \\
\text { delivery }\end{array}$ & 3 & 25 \\
\hline $\begin{array}{l}\text { Active involvement of } \\
\text { ASHA worker }\end{array}$ & 3 & 25 \\
\hline $\begin{array}{l}\text { Education to health } \\
\text { worker }\end{array}$ & 2 & 16.66 \\
\hline
\end{tabular}

\section{MI coverage status}

Out of 18 studies,16 studies in which FI was reported were considered to assess the MI coverage status. Studies conducted in Manipur, Madhya Pradesh, South Kerala and Bihar reported successful achievement of $90 \%$ immunization coverage (Figure 2).

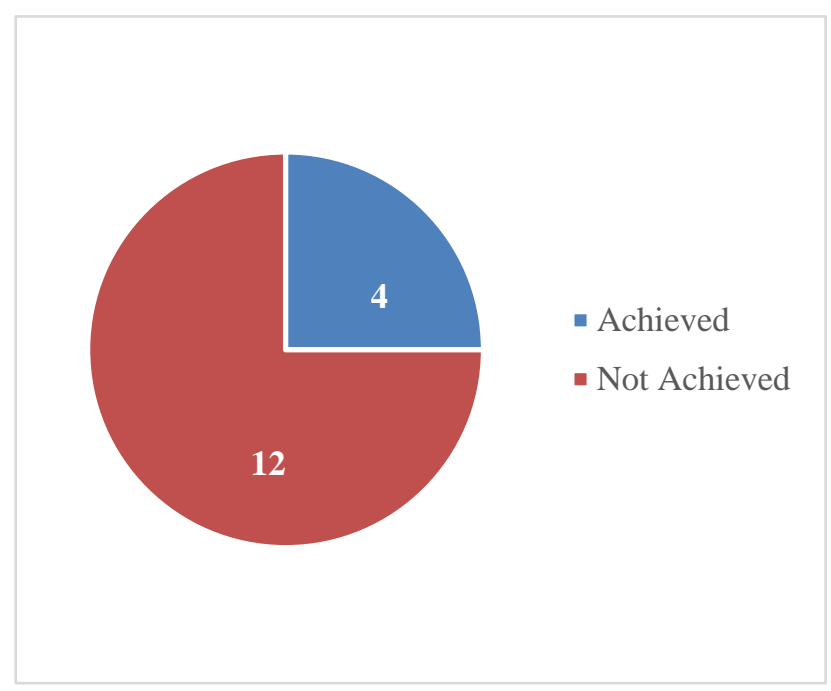

Figure 2: MI coverage status $(n=16)$. 


\section{DISCUSSION}

The national family health survey (NFHS-4) conducted during 2015-16, contains some key indicators that reflects the country's present status. The key indicators include infant and child mortality rates, maternal and child health, child immunization and vitamin A supplementation, child feeding practices, nutritional status and many more. ${ }^{24}$ As per the analysis of NFHS-4, infant mortality rate (IMR) has reduced from 57 to 41 per thousand live births and a higher reduction has been seen in under-5-mortality rate from 74 to 50 per thousand live births. The state with the highest IMR was Uttar Pradesh (64 per 1000 live births) and that with the lowest IMR was Kerala (6 per 1000 live births). ${ }^{3}$ At the national level, the percentage of children aged 12-23 months who were fully immunised (one dose of BCG, three doses of diphtheria, pertussis and tetanus (DPT) vaccine, and one dose of measles vaccine) increased by $18 \%$ points from $44 \%$ in $2005-06$ to $62 \%$ in $2015-16 .^{24}$

A study conducted in Bihar reported higher BCG $(99.2 \%)$, OPV $(1,2,3)(97.2 \%)$ and measles coverage $(92.5 \%)$ which was comparatively higher than that reported in NFHS-4. ${ }^{25}$ A study conducted in Ahmedabad district of Gujarat reported BCG coverage $(85.7 \%)$ and measles coverage $(74.6 \%)$ which was similar to the data reported by NFHS- $4 .{ }^{26} \mathrm{~A}$ district level analysis done in India reported BCG coverage $(85.9 \%)$, DPT $(1,2,3)$ $(70.7 \%)$ and measles coverage $(71.2 \%)$ which in contrast was lower than the NFHS-4 data fact sheet. ${ }^{27}$ Similarly study conducted in Telangana reported BCG coverage $(96.7 \%)$ which was similar to the NFHS-4 fact sheet, whereas measles coverage $(85.3 \%)$ which was comparatively lower than the data reported by NFHS-4 fact sheet. ${ }^{28}$

All the sixteen studies reviewed for the evaluation of universal immunization coverage concluded that four states have achieved the MI goal that was Madhya Pradesh (91.2\%), Bihar (90.85\%), Manipur (91.90\%) and South Kerala (96.40\%). Some states have achieved more than $80 \%$ immunization coverage such as Telangana $(83.60 \%)$ and Vellore (84\%). ${ }^{11-13,15,18,21}$

Most common reason reported for partial and no immunization includes lack of information, illiteracy, childhood illness, mother too busy in their work, unavailability of vaccination at health centres, religion disparity and vaccination site too far away from home. A study conducted in Madhya Pradesh revealed that more than $90 \%$ of the children were completely immunized or fully immunized which were only $69 \%$ before the implementation of MI programme. Other than the most common barriers, this study focused on various other determinants such as myths about vaccination like impotency, disease and death, lack of interest of villagers towards vaccination and migration of villagers as a responsible factors for not availing $100 \%$ immunization. ${ }^{13}$ A study conducted in south India (Vellore) mentioned that misplaced vaccination card on due date and unavailability of health care workers at the immunization site to record the date of immunization were also some of the other determinants for partial or no immunization. ${ }^{15}$

Most of the studies reported certain common solutions to remove barriers in achieving full immunization coverage such as promoting health education campaigns, strengthening IEC services related to MI program, promoting institutional deliveries, active involvement of ASHA worker in immunization awareness program and at immunization session site and education to health workers.

Apart from all these solutions, a study conducted in Lucknow (Uttar Pradesh) suggested that surveillance and referral system in the area needs to be reinforced so as to identify defaulters of immunization and to reduce dropout rates. ${ }^{14}$ Whereas a study conducted in Mumbai emphasis on scaling up use of post-natal services and a study conducted in Madhya Pradesh suggested the need for intensive planning of immunization campaigns. ${ }^{9,13}$

A descriptive study conducted in urban slum of Ludhiana found that only $0.5 \%$ mothers had good knowledge regarding immunization, on contrary a cross sectional study conducted in south Kerala revealed, $48 \%$ of mothers had good knowledge. ${ }^{18,23}$ A study conducted in Bangalore concluded $72.7 \%$ care givers had good knowledge, $21.8 \%$ had average knowledge and $5.40 \%$ have poor knowledge. ${ }^{20}$

Furthermore, a cross-sectional study conducted. in Madhya Pradesh (Indore) revealed, $88 \%$ care givers were aware about immunization. ${ }^{13}$ A cross sectional study conducted among 100 selected mothers in Rudraprayag town of Uttarakhand found that $97 \%$ mothers have adequate knowledge regarding immunization and vaccination whereas only $3 \%$ have inadequate knowledge. ${ }^{19}$

\section{Strengths and limitations}

The review has provided summary statistics of MI in last 5 years. Information related to number of immunization session planned under the program, evaluation of cold chain and logistics managements, human resource availability at the immunization session site were not included due to unavailability of the information in the selected articles.

\section{CONCLUSION}

The most common reason for not achievement of MI goal was lack of awareness, illiteracy, child illness and fear of adverse effects. Further research studies could be conducted to evaluate health system readiness for MI. This would be helpful in identifying the bottlenecks in implementation of the program and formulation of strategies to overcome it. 
Funding: No funding sources

Conflict of interest: None declared

Ethical approval: Not required

\section{REFERENCES}

1. Tobergte D R, Curtis S. Mission Indradhanush. J.Chem.Inf.Model. 2013;53:1689-99. Availaiblefrom:https://main.mohfw.gov.in/sites/defa ult/files/216846291201489665182.pdf.

2. Government of India Ministry of health and family welfare 2020 Intensified Mission Indradhanush 2-3. Available

from: https://www.aspirationaldistricts.in/wpcontent/uploads/2019/02/Mission-Indradhanush.pdf. Accessed on 30/5/2020.

3. Dhirar N, Dudeja S, Khandekar J, Bachani D. Childhood Morbidity and Mortality in India-Analysis of National Family Health Survey 4 (NFHS-4) Findings. Indian Pediatr. 2018;55:335-8.

4. Singh A. Mission Indradhanush (MI) and Intensified Mission Indradhanush (IMI): The Immunization Programmes in India - A Brief Review. Gut Gastroenterol. 2018;1:001-2.Available from http://sciaeon.org/articles/Mission-Indradhanush(MI)-and-Intensified-Mission-Indradhanush-(IMI)The-Immunization-Programmes-in-India.pdf.

5. Maschinen $B$, Investition A, Beschaffungen $G$, Ersatzbeschaffungen B, Mittelherkunft S. No TitleRoad map for achieving $90 \%$ full immunization coverage. Ministry of Health and Family welfare. Available from: https://nhm.gov.in/New_Updates_2018/NHM_Comp onents/Immunization/Guildelines_for_immunization/ Roadmap_document_for_90\%25_FIC.pdf. Accessed on $30 / 5 / 2020$.

6. Prinja S, Monga D, Rana SK, Sharma A, Dalpath S, Bahuguna $P$ et al. District level analysis of routine immunization in Haryana State: Implications for mission indradhanush under universal immunization programme. Indian J community medicine, Indian Asso Preven Social Med. 2018;43:209.

7. Murhekar MV, Kamaraj P, Kanagasabai K, Elavarasu G, Rajasekar TD, Boopathi K et al. Coverage of childhood vaccination among children aged 12-23 months, Tamil Nadu, 2015, India. Indian J Med Res. 2017;145:377.

8. Mohapatra I, Kumar A, Mishra K. A study on awareness and utilization of Mission Indradhanush in an urban slum of Bhubaneswar. J Family Med Pri Care. 2018;7:1294.

9. Singh S, Sahu D, Agrawal A, Jeyaseelan L, Nadaraj A, Vashi MD. Coverage, quality, and correlates of childhood immunization in slums under national immunization program of India: A cross-sectional study. Heliyon. 2019;5:e02403.

10. Algotar PD, Lakshmi N, Yagnik HB, Jain R. Process evaluation of mission Indradhanush immunization program in urban and rural communities of
Ahmedabad district of Gujarat. Int $\mathbf{J}$ Comm unity Med Public Health. 2019;6:780.

11. Chavan GM, Mavatkar MV. Assessment of Immunization Coverage of Pediatric Population in Telangana. Community Med. 2019;10:203-6.

12. Kameshore $\mathrm{N}$, Joymati $\mathrm{O}, \mathrm{Kb} \mathrm{S}$. Coverage Evaluation Survey of the Universal Immunization Program in North- Eastern India. Ann Int med Dental res. 2017;3:1-5.

13. Jain A, Gupta N, Singh A, Singh R, Dubey R. A Study on Mission Indradhanush Programme under Reproductive and Child Health Among Rural Population of Tikamgarh District of Madhya Pradesh. J Scie Res Dev. 2018;6:265-8.

14. Gupta P, Prakash D, Srivastava JP. Determinants of immunization coverage in Lucknow district. N Am J med sci. 2015;7:36.

15. Francis MR, Nuorti JP, Kompithra RZ, Larson H, Balraj V, Kang $G$ et al. Vaccination coverage and factors associated with routine childhood vaccination uptake in rural Vellore, southern India, 2017. Vaccine. 2019;37:3078-87.

16. Mugada V, Chandrabhotla S, Kaja DS, Machara SG. Knowledge towards childhood immunization among mothers and reasons for incomplete immunization. $\mathbf{J}$ App Pharm Sci. 2017;7:157-61.

17. Shrivastwa N, Gillespie BW, Kolenic GE, Lepkowski JM, Boulton ML. Predictors of vaccination in India for children aged 12-36 months. Am J prev med. 2015;49:S435-44.

18. Navaneetha N, Abraham SB, Thomas T, Mary R, Bhuvanendu HA. Knowledge and perceptions regarding immunization among mothers of under five children: a community study from South Kerala. Int $\mathbf{J}$ Contemporary Pediatr. 2020;7:66.

19. Singh S, Rawat MS. Awareness Attitude and Utilization of Universal Immunization Program with Reference to Mission Indradhanush in Rudraprayag Town of Uttarakhand. Studies Indian Place Names. 202013;40:1481-90.

20. Trushitkumar BP, Pathak R, Singh R, Alves V, Mahesh NM, Chaluvaraj TS et al. Assessment of Parents' Knowledge, Attitude and Practice about Child Vaccination in Rural areas. J Pharmaceu Res. 20171;16:229-36.

21. Singh CM, Mishra A, Agarwal N, Mishra S, Lohani $\mathrm{P}$, Ayub A. Immunization coverage among children aged 12-23 months: A cross sectional study in low performing blocks of Bihar, India. J Fam Med Pri Care. 2019;8:3949.

22. Patidar A, Khatri A, Waskel B, Dixit S. A cross sectional study to assess the awareness and satisfaction level among the beneficiaries regarding Mission Indradhanush in selected districts of Indore division. Int J Comm Med Pub Health. 2019;6:378791.

23. Kaur H, Gupta VK, Chaudhary A, Girdhar S, Bansal P, Singh S. Perceived Barriers of Child Immunization among Mothers of Under-5 Children in Urban Slum of Ludhiana City. Hindu.106:53-0. 
24. Ram F, Paswan B, Singh SK, Lhungdim H, Sekhar C, Singh A. National family health survey-4 (201516). Econ Pol Weekly. 2017;52:66-70.

25. Sheet S F 2015 National Family Health Survey - 4 State Fact Sheet Bihar retrieved from http://rchiips.org/NFHS/pdf/NFHS4/BR_FactSheet.p df. Accessed on 14 May 2020.

26. Sheet S F 2015 National Family Health Survey - 4 State Fact Sheet Gujarat. Available at: http://rchiips.org/nfhs/pdf/NFHS4/GJ_FactSheet.pdf Accessed on 14 May 2020.

27. Sheet S F 2015 National Family Health Survey -4 India fact sheet, Available at: http://rchiips.org/
NFHS/pdf/NFHS4/India.pdf. Accessed on 14 May 2020.

28. Sheet S F 2015 National Family Health Survey - 4 State Fact Sheet Telangana. Available at: http://rchiips.org/nfhs/pdf/NFHS4/TG_FactSheet.pdf . Accessed on 14 May 2020.

Cite this article as: Thakur R, Awasthi AA, Taneja $\mathrm{N}$, Janardhanan R. The evaluation of immunization coverage under mission Indradhanush: a review. Int $\mathrm{J}$ Community Med Public Health 2020;7:5229-36. 